\title{
INTER-RELAÇÕES ENTRE ESPAÇO FÍSICO, MODO DE VIDA MBYÁ-GUARANI E ALIMENTAÇÃÓ NA PERSPECTIVA DA SEGURANÇA ALIMENTAR: REFLEXÕES SOBRE A ÁREA INDÍGENA ARAÇA-ÍI EM PIRAQUARA/PR
}

SYMONE CORTESE DA SILVA AUZANI ${ }^{1}$

$U F P R$

RUBIA CARLA FORMIGHIERI GIORDANI ${ }^{2}$

$U F P R$

RESUMO: Este trabalho é um estudo qualitativo sobre as inter-relações entre espaço fisico, modo de vida e cultura alimentar entre os Mbyá-Guarani moradores da aldeia Karuguá (Paraná). No primeiro momento discute-se a localização espacial e uma descrição sobre os elementos que a compõem. No segundo momento surge o significado de ser um Mbyá-Guarani e suas inter-relações com o ambiente e com as práticas alimentares dessa etnia. Na terceira parte do trabalho, busca-se promover uma reflexão sobre a relação entre a alimentação tradicional e a alimentação atual, enfatizando os aspectos referentes ao direito humano à alimentação adequada no contexto da Segurança Alimentar e Nutricional, com ênfase nos aspectos culturais. Por fim os direitos indígenas e as leis criadas pelo Estado brasileiro são problematizadas, pois evidencia-se que elas não garantem a realização do Direito Humano a alimentação Adequada.

PALAVRAS-CHAVE: Mbyá-Guarani; Cultura alimentar; Segurança Alimentar $e$ Nutricional; Direito Humano a Alimentação Adequada.

\begin{abstract}
This work is a qualitative study about the relation between the physical space, lifestyle and eating habits among the Mbyá-Guarani living in the Karuguá (Paraná). In the first stage, the spatial location of the Karuguá community as well as the elements that compose it are discussed. In the second stage, the meaning of being a Mbyá-Guarani and their relation with the environment and with the eating habits of this ethny are outlined. In the third stage, a reflexion over the relation between traditional eating habits and current eating habits stressing their cultural aspects is made, emphasizing what concerns the Human Right to Adequate Food and Nutrition in the context of Food and Nutritional Security. Finally, the issues around indian rights and the laws created by the Brazilian government are discussed, since it becomes clear that it does not assure the Human Right to Adequate Food and Nutrition.
\end{abstract}

KEYWORDS: Mbyá-Guarani; Food culture; Food Security; Human Right to Adequate Food and Nutrition;

\footnotetext{
${ }^{1}$ Graduação em Nutrição, bolsista de Iniciação Científica no Departamento de Nutrição da Universidade Federal do Paraná. E-mail: syauzani14@yahoo.com.br.

${ }^{2}$ Doutoranda em Sociologia. Professora do Departamento de Nutrição da Universidade Federal do Paraná. Núcleo de Segurança Alimentar e Nutricional-Departamento de Nutrição/UFPR/Ministério da Ciência e Tecnologia; e membro do Grupo de Pesquisa em Sociologia da Saúde, CNPq/UFPR. E-mail. rubia@ufpr.br.
}

Espaço Ameríndio, Porto Alegre, v. 2, n. 1, p. 129-165, jan./jun. 2008. 


\section{Introdução}

Existem no Brasil cerca de 590 mil indígenas, que pertencem a 252 etnias, falando aproximadamente 200 línguas e dialetos, ocupando $11 \%$ do território nacional. O significado do termo "indígena" não remete mais a questão biológica ou racial, mas a questão cultural, a uma ligação com o passado desses povos (HECK e PREZIA, 1999).

Dentre os povos indígenas brasileiros estão os Guarani, que pertencem à família Tupi-Guarani, do tronco lingüístico Tupi. Habitavam a América do Sul antes da invasão européia, tendo sido estimados em dois milhões de pessoas. Os Guarani do Brasil são divididos em três subgrupos de acordo com o dialeto, os costumes e as práticas rituais: Kayová, Ñandéva e Mbyá. Atualmente, os Mbyá-Guarani localizam-se em áreas no Uruguai, Paraguai, Argentina e Brasil, onde habitam os estados do sul do país (Rio Grande do Sul, Santa Catarina e Paraná) e os estados de São Paulo, Rio de Janeiro, Espírito Santo e Mato Grosso do Sul, além de algumas famílias encontrarem-se no Pará e no Tocantins. A localização espacial das aldeias Mbyá-Guarani ocorre preferencialmente em áreas próximas ao mar, sobretudo nas serras da Mata Atlântica. Algumas etnografias mostraram que a preferência por essas áreas é explicada pela busca do paraíso Mbyá-Guarani, denominado Terra Sem Mal, que estaria localizada nas proximidades do Oceano Atlântico e onde os Mbyá-Guarani poderiam viver sem sofrimentos (FELIPIM, 2001; HECKLER, 2006; LITAIFF, 1996; LADEIRA, 2007).

O termo Mbyá significa, de acordo com Bonamigo (2006, p. 1) "muita gente num só lugar". Os Mbyá-Guarani são vistos pelos demais indígenas como os habitantes da selva, pois conforme Litaiff (1996) eles não viveram em reduções jesuíticas depois da invasão dos europeus, o que garantiu a eles o mínimo possível de contato com não-indígenas.

A população estimada de Guarani no Brasil gira em torno de 34.000 pessoas, entre os Kayová (18.000 a 20.000), Ñandéva (8.000 a 10.000) e Mbyá (5.000 a 6.000) (CTI, 2007). No Paraná, o número de

Espaço Ameríndio, Porto Alegre, v. 2, n. 1, p. 129-165, jan./jun. 2008. 
indígenas chega a aproximadamente 10.000 indivíduos de várias etnias (HECK e PREZIA, 1999).

Os Mbyá-Guarani buscam instalar suas aldeias em territórios tradicionais, principalmente nas regiões litorâneas, que, anteriormente eram ocupados por seus ancestrais, por acreditarem que migrando encontrarão a Terra Sem Mal. As migrações ocorrem sempre em direção ao litoral, por acreditarem que a localização da Terra Sem Mal está além do oceano. A história de aldeamento entre os Mbyá-Guarani é recente e eles buscam locais onde possam isolar-se da sociedade envolvente, para cultivarem seus hábitos tradicionais de vida. As aldeias são denominadas de tekoa e devem conter os recursos naturais que possibilitem a vivência do jeito de ser Mbyá-Guarani, denominado por eles de nhandereko. Entretanto, a divisão atual das aldeias, definidas por limites artificiais com relação a outras ocupações (tais como fazendas, loteamentos, estradas, projetos de abastecimento, etc.), inviabiliza-as enquanto espaço que garanta a subsistência da própria comunidade (CTI, 2007). A localização das aldeias Mbyá-Guarani, em locais com escassez de recursos naturais tem implicações sérias sobre seu modo de vida e suas condições de saúde. De acordo com Litaiff (1996, p. 32-33) "os Guarani, encontram-se hoje em uma situação de miséria, pobres e desterrados" sendo comum a subnutrição e o alcoolismo. A redução da população Mbyá-Guarani está associada à falta de terras para o plantio de roças tradicionais, para a coleta de frutos e remédios no mato e para a caça (LITAIFF \& DARELLA, 2000). Além disso, conflitos com outras etnias, como Kaingáng e Xokleng como acontece em Santa Catarina -, por disputas de terras e poder, têm provocado abandono das aldeias pelos Mbyá-Guarani.

Para os Mbyá-Guarani a manutenção de sua língua viva é sinônimo de conservação da cultura e marca definidora de sua identidade, diferenciando-os dos demais grupos (LITAIFF, 1996). Outro fator importante para a conservação de sua etnicidade é a alimentação que incorpora vários aspectos peculiares à cultura desse povo, sobretudo no que se refere ao tratamento atribuído ao milho, o milho guarani. Através do milho, durante a cerimônia do batismo, os MbyáGuarani recebem seu nome guarani, seu espírito (TEMPASS, 2005).

Espaço Ameríndio, Porto Alegre, v. 2, n. 1, p. 129-165, jan./jun. 2008. 
Contudo, apesar dos Mbyá-Guarani procurarem viver de acordo com suas tradições, as transformações ambientais, econômicas e sociais estão interferindo na vida desse grupo. Pela falta de terras ou pelas condições desfavoráveis dos seus territórios, com limitações territoriais ou exaustão de recursos naturais, eles vivem em situações de vulnerabilidade alimentar.

São raros os estudos de prevalência de doenças entre os MbyáGuarani, entretanto pesquisas realizados no Brasil com outras etnias têm demonstrado que há uma situação de clara desvantagem indígena quando comparada com a sociedade nacional (SANTOS, 1993; COIMBRA JR e SANTOS, 1991; RIBAS et al, 2001; LEITE et al, 2006).

A insegurança alimentar e nutricional na qual os grupos indígenas vivem, provoca uma série de complicações na sua saúde, principalmente entre as crianças. Pela falta de alimentos ou pela monotonia da dieta, ocorre a desnutrição ou subnutrição, podendo acarretar no surgimento de doenças carenciais, como anemias, hipovitaminose $A$, cáries e nanismo nutricional (RIBAS et al, 2001; COIMBRA JR e SANTOS, 1991). A desnutrição energético-protéica crônica favorece o aparecimento de doenças infecciosas respiratórias ou diarréicas, que associadas a condições de vida insalubres e a doenças parasitárias, podem provocar a morte dessas crianças. Além disso, o contato com a sociedade envolvente, que ocorre devido à proximidade das aldeias com as cidades, ocasiona o aparecimento de novas doenças entre os indígenas, como doenças sexualmente transmissíveis (DST) e até mesmo a síndrome da imunodeficiência adquirida (AIDS) (CONFALONIERI, 1989). Essa aproximação traz também a inserção de alimentos industrializados nas aldeias, ocasionando o aparecimento de doenças crônicas não transmissíveis, como diabetes, hipercolesterolemia, doenças coronarianas e cardíacas (BONAMICO, 2006).

A maneira como os indígenas sobrevivem hoje, vivendo dispersos em pequenos grupos, com privação de terras, em disputas pela demarcação dos seus territórios, lutando pela ampliação das áreas anteriormente demarcadas, resistindo às mudanças ambientais e culturais a que são submetidos ou adaptando-se de alguma maneira aos hábitos da sociedade envolvente, são retratos dos indígenas na atualidade, que vêm, há muito tempo, perdendo qualidade de vida. $\mathrm{O}$

Espaço Ameríndio, Porto Alegre, v. 2, n. 1, p. 129-165, jan./jun. 2008. 
contato dos indígenas com a sociedade nacional trouxe conseqüências dramáticas a eles, como prevalência de doenças, fome, morte e transformação da sua cultura, situação que persiste até hoje, em maior ou menor gravidade, dependendo do local no qual vivem, das condições sócio-econômicas do grupo e de suas características culturais (HÖKERBERG, DUCHIADE e BARCELLOS, 2001). Todas essas dificuldades, aliadas a ocupação de áreas inadequadas para o cultivo de roças, para a coleta de frutos e para a prática da caça e da pesca, implicam na dificuldade que os indígenas encontram em manter seu jeito de ser, que passa pela religião, pelo cultivo e consumo de alimentos sagrados e pelas transformações que estão ocorrendo em suas aldeias. Todos esses fatores contribuem de alguma maneira à insegurança alimentar e nutricional que os indígenas vivem hoje.

Este trabalho teve por objetivo geral compreender como as relações entre o meio ambiente e sociedade estão articuladas e interferem na concretização do Direito Humano à Alimentação Adequada no caso específico dos Mbyá-Guarani que habitam a área indígena Araçá-í - Aldeia do Karuguá no município de Piraquara - PR. Buscou ainda descrever o espaço físico e social onde se localiza a aldeia e suas implicações na alimentação dos Mbyá-Guarani que vivem lá; analisar a concretização da Segurança Alimentar e Nutricional (SAN) sob a perspectiva da cultura alimentar e modo de vida - Nhandereko- dos Mbyá-Guarani; problematizar o direito indígena à alimentação adequada em sua relação à Segurança Alimentar e Nutricional e finalmente problematizar os direitos indígenas e as leis criadas pelo Estado brasileiro, pois se evidencia que elas não garantem a realização do Direito Humano à Alimentação Adequada.

O trabalho de campo ocorreu entre os meses de abril e outubro de 2007 para a realização da observação participante e entrevistas coletadas com índios que vivem no Karuguá, além da pesquisa documental e histórica da constituição da área indígena.

\section{As inter-relações entre o ambiente e a cultura Mbyá-Guarani}

\section{A localização da aldeia do Karuguá}

Espaço Ameríndio, Porto Alegre, v. 2, n. 1, p. 129-165, jan./jun. 2008. 
Os indígenas Mbyá-Guarani, da aldeia Karuguá, localizada no município de Piraquara/PR, na Região Metropolitana de Curitiba, estão dentro da Área de Preservação Ambiental (APA) da Bacia do Iraí, próximo à barragem de Piraquara I, que contribui no abastecimento de água da Região Metropolitana de Curitiba. De acordo com informações disponíveis no endereço eletrônico da Prefeitura de Piraquara, os indígenas encontram-se em um local do qual detém a posse, mas que não é considerado reserva indígena (PREFEITURA MUNICIPAL DE PIRAQUARA, 2007).

Foram construídas quinze casas pelos próprios indígenas e um campinho de futebol que serve como espaço para a prática da disciplina de educação física da escola. A prefeitura instalou na aldeia banheiros coletivos com vasos sanitários e chuveiros, além de tanques para a lavagem de roupas e louças e torneiras no chão para o acesso à água potável.

A maior construção da aldeia é a Casa de Reza - opy - , uma casa de pau-a-pique, de chão batido, telhado de capim localizada no mapa residencial local no centro das demais casas e ao lado da casa do Cacique Marcolino que também é o pajé. A Casa de Reza, um espaço de sociação, é por natureza o lugar do encontro. Pissolato (2007, p. 380) relata que "é possível ouvir entre os mbyá, geralmente em falas discretas, que em determinada aldeia 'não tem pajé'", mas é pouco provável encontrarmos uma aldeia mbyá sem opy. A opy tem o caráter da reunião, da comunhão e os guarani "a compreendem vinculada, em alguma medida, a uma função de proteção divina" (PISSOLATO, 2007, p. 380). Ali são realizadas as rezas e os ensinamentos onde todas as noites os moradores da aldeia ouvem o Cacique/pajé falar sobre o modo de vida Guarani. No tempo de convivência com os Mbyá-Guarani do Karuguá, observamos que o almoço da família do Cacique é preparado na Casa de Reza e que depois da comida pronta o grupo se reúne dentro dela e dispostos em círculo, sentados no chão, fazem sua refeição para depois degustarem o chimarrão e o cachimbo.

A escola indígena do Karuguá denominada Mbyá Arandú Sabedoria Guarani - é uma construção de madeira, com cobertura de telhas. É uma escola bilíngüe, na qual são repassados e reforçados

Espaço Ameríndio, Porto Alegre, v. 2, n. 1, p. 129-165, jan./jun. 2008. 
aspectos referentes à cultura guarani além dos conteúdos currículares para o ensino fundamental. Ela é constituída por quatro ambientes, quais sejam: duas salas-de-aula amplas, uma cozinha e um escritório que serve também como quarto para apoio aos professores que vão de Curitiba para a aldeia e dormem lá. Nas salas-de-aula existem mesas e cadeiras adequadas às crianças, um quadro negro, alguns desenhos feitos pelas crianças, representando a aldeia, a mata ao redor, a represa, alguns bichos, como pássaros, jacarés e costumes guarani. Pendurado na parede está o alfabeto escrito na língua guarani e em português, com fotografias e desenhos que lembram a cultura Mbyá-Guarani. Em uma das salas-de-aula estão depositados vários computadores bastante empoeirados aguardando a vinda de um técnico de informática à aldeia para a instalação e utilização pelas crianças. Além dos computadores, há estantes e caixas contendo muitos livros pedagógicos, que parecem não serem utilizados.

$\mathrm{Na}$ escola há uma cozinha, onde é preparada a alimentação escolar. Os gêneros são fornecidos pelo Departamento da Alimentação Escolar da Secretaria Estadual de Educação, através do Programa Nacional de Alimentação Escolar, que destina atualmente uma verba de $\mathrm{R} \$$ 0,44 per capita, por 200 dias letivos para uma refeição/lanche por dia. A merendeira é Dona Natalina, esposa do Cacique Marcolino, que diariamente prepara o lanche para as crianças e o serve individualmente na hora do intervalo, supervisionando com cuidado a refeição das crianças. A cozinha está equipada com uma geladeira, pia de lavar louça, armários, uma mesa, uma batedeira industrial e um fogão a gás. Dentre os gêneros disponíveis há leite em pó, sucos, chá mate, achocolatado, arroz, feijão, macarrão, bolachas, misturas para bolos, fubá, alimentos enlatados, principalmente carnes em conserva, milho e ervilha. A fruteira, sem frutas, guarda apenas alguns vegetais velhos e murchos como cenoura, cebola e batatas, sem muita apreciação das crianças. As bolachas, pães, achocolatados e sucos parecem ser os gêneros mais aceitos e consumidos na alimentação escolar.

O espaço físico: as casas e a manutenção da vida Mbyá-Guarani

Espaço Ameríndio, Porto Alegre, v. 2, n. 1, p. 129-165, jan./jun. 2008. 
Internamente as casas da aldeia são divididas basicamente em dois espaços: um ambiente semelhante a uma sala-de-estar, onde observamos colchões e cadeiras, fogões a gás ou o espaço do fogo de chão e utensílios que são usados no dia-a-dia e outro ambiente, mais íntimo, o quarto. Nas casas existem basicamente uma porta e duas ou três janelas, conforme o tamanho da moradia. A disposição delas é semelhante a um círculo, formando o centro da aldeia, com a Casa de Reza, a escola e a unidade de saúde, voltadas para o centro. As portas das casas também estão voltadas para o centro da aldeia. Observamos que as casas servem para o repouso noturno e que durante o dia, os indígenas passam a maior parte do tempo do lado de fora delas. Normalmente estão fazendo artesanato ou conversando ao sabor do chimarrão e do cachimbo ao redor de uma fogueira. Para os Guarani o significado de casa é mais amplo: eles consideram sua casa todo o espaço da aldeia, e a sua casa - construção - é para eles a intimidade. Possivelmente poderíamos comparar o ambiente da aldeia como a casa juruá e a casa - construção Guarani- como o quarto do juruá. Na maioria das vezes, eles não convidam os visitantes para entrar na casaconstrução, pois consideram que os visitantes já estão acomodados na sua casa. Segundo Bonamigo:

[...] a casa é um espaço doméstico na qual só entra quem é convidado. [...] a casa de cada um é um espaço reservado [...] a casa é considerada local das refeições e de pernoite, pois dizem que moram no tekoa, que pertence a todos e propicia sua prática de vida (BONAMIGO, 2006, p. 35 e p. 39).

Por tekoa entende-se a terra, que é percebida como um ambiente sócio-político, significando jeito de ser, de estar, lei, sistema, cultura, norma, comportamento Guarani. É o local que apresenta as condições de se exercer o jeito de ser Guarani. O tekoa deve ser dirigido conforme a religião e a agricultura de subsistência (LADEIRA, 1994, p. 49). Conforme afirma Litaiff (1996, p. 50), tekoa significa "terra fértil, mata virgem, lugar de caça e coleta" e o manejo e conjugação desses elementos e seres da natureza é que determina a própria dinâmica da

\footnotetext{
${ }^{3}$ Juruá é a expressão Guarani utilizada pelos índios para se referir aos não-índios. Algumas vezes é utilizado como sinônimo para brancos, ou, de acordo com Litaiff (1996, p. 51) o termo pode ser definido ainda como civilizado.
}

Espaço Ameríndio, Porto Alegre, v. 2, n. 1, p. 129-165, jan./jun. 2008. 
tekoa (LADEIRA, 2001). Assim, para que os Mbyá-Guarani cultivem seus hábitos tradicionais, como religião, alimentação, práticas de saúde, fazse necessário que o ambiente por eles habitado seja percebido como tekoa, favorecendo sua integração com a natureza para a manutenção do jeito de ser Mbyá-Guarani.

A aldeia é constituída por um espaço no qual existem casas com a arquitetura típica guarani, construídas pelos próprios moradores. Algumas apresentam uma varanda, onde acendem o fogo de chão. Em outras, o fogo é acesso dentro de casa ou ainda em um local mais afastado dela, pois segundo Silvio, um jovem guarani que vive no Karuguá, muitos Guarani estão ficando cegos ainda jovens devido à fumaça oriunda do fogo de chão.

O fogo é acesso com pedaços grossos de madeira e fica acesso praticamente o dia todo, pois ali os guarani permanecem em grupos ou sozinhos tomando chimarrão e fazendo artesanato. O fogo e a fumaça são elementos afirmadores e tradicionais na cultura guarani surgindo como forma específica de sociabilidade. De acordo com Bonamigo (2006, p. 57) o fogo é utilizado para "espantar insetos ou o mal em geral. No último caso, o sentido está na fumaça que lhes lembra a fumaça sagrada que sai do cachimbo em direção a Nhanderu (deus supremo Mbyá-Guarani)".

$\mathrm{Na}$ maioria das casas existem pequenos espaços cultiváveis fechados com tela, ou cerca de bambu e destinados para pequenas roças onde plantam basicamente feijão, milho e couve. Hélio que também é oriundo de Mangueirinha e vive no Karuguá há pouco mais de dois anos nos levou para conhecer as hortas e contou que são cercadas por que na aldeia são criadas pequenas aves como galinhas e patos. De acordo com Hélio esses animais servem de alimento para as famílias, já que a caça, a pesca e animais de grande porte são proibidos.

Dentre todas as casas havia uma que se destacava das demais pelo modelo da construção. A casa é de madeira e se distingue da arquitetura guarani vista na aldeia, pois se assemelha a uma construção típica da sociedade envolvente. Os donos da casa são Júlio e Cleuza, que vieram para o Karuguá por terem gostado do lugar. Cleuza é Ñandéva e Júlio é filho de pai Mbyá-Guarani e mãe Xakriaba. Moraram em vários estados do Nordeste tanto em áreas urbanas quanto indígenas. Antes de

Espaço Ameríndio, Porto Alegre, v. 2, n. 1, p. 129-165, jan./jun. 2008. 
chegarem em Piraquara, há aproximadamente três anos, viveram por algum tempo em áreas guarani no Estado de São Paulo. Júlio é o responsável por divulgar as tradições dos Mbyá-Guarani do Karuguá. É ele quem faz palestras em escolas da região sobre as tradições indígenas e quem organiza as apresentações do grupo nos eventos que realizam para ganharem algum dinheiro.

Conversando com Cleuza, ela contou que viveu muito tempo fora da aldeia onde nasceu, pois casou cedo e foi morar na cidade. Relata que seu ex-marido bebia e gastava todo o dinheiro que ganhava na cidade obrigando-a procurar emprego de doméstica para sustentar sua filha pequena. Por isso, ela aprendeu a viver como não-indígena e a ter costume de juruá, principalmente no que se refere a atividade doméstica.

[...] eu fui aldeiada até os 14 anos, depois eu casei e fui pra cidade [...] sempre eu vivi no meio dos branco, depois voltei pra aldeia, porque o índio não pára... (referindo-se aqui às viagens que fez para morar e conhecer outros lugares do interior do estado de São Paulo, morando tanto em aldeias indígenas quanto na cidade) quando eu nasci, as casa, rancho, era tudo de pau-a-pique, não tinha luz, essas coisa que têm hoje, depois com o tempo foi evoluindo [...] na minha aldeia (referindo-se à aldeia na qual nasceu) hoje é tudo civilizado, tem luz, água, casa de material, televisão [...] (CLEUZA, 2007).

"Arear" panelas de alumínio com palha de aço e detergente, fazer a limpeza da casa com material químico, lavar roupas em tanque com sabão em pó e água sanitária são alguns dos hábitos de Cleuza. Os utensílios e as panelas utilizadas na casa também são diferentes dos demais, ao contrário de panelas de barro utilizam panelas de alumínio.

Quando perguntamos à Cleuza sobre essa mudança de hábitos de vida, ela respondeu:

[...] é ruim, pois a vida do branco é muito corrida, então eu peguei o pique de vocês [...] eu tenho minha parte de índio, mas a maior já tá lá pro lado de branco, porque eu aprendi (referindo-se aos seus costumes com relação a maneira como conduz seus afazeres domésticos) [...] os branco ficam limpando a casa todos os dias, dobrar roupa e eu peguei o hábito do

Espaço Ameríndio, Porto Alegre, v. 2, n. 1, p. 129-165, jan./jun. 2008. 
branco e eu não consigo não fazer $[\ldots]($ CLEUZA, 2007).

O contato prolongado com a sociedade envolvente levou à incorporação de outros hábitos que para Cleuza parecem ruins. As transformações poderiam estar associadas à relativa proximidade das aldeias com as cidades facilitando a inter-relação entre os elementos tradicionais e a cultura juruá. No Karuguá, em algumas casas há televisão, e os indígenas se divertem assistindo a programas de TV. Hélio nos contou que os programas preferidos são os programas com o apresentador Sílvio Santos, o programa humorístico "Chaves" e as novelas da rede Globo.

O contato dos indígenas com a sociedade envolvente e a incorporação de hábitos ocidentalizados observados no Karuguá faz parte de um processo de transformação da cultura Mbyá-Guarani. Segundo Ladeira (1994) esse processo vem ocorrendo desde a conquista do território brasileiro pelos europeus, afirmando que essas transformações foram sendo incorporadas ao cotidiano como uma forma de preservação da cultura e de estabelecimento de relações pacíficas com a sociedade envolvente.

Os Guarani Mbya, às custas do contato antigo e intenso com os brancos, caracterizado por perseguições culturais e físicas, desenvolveram vários mecanismos para guardar e viver suas tradições culturais e religiosas, garantindo sua reprodução enquanto povo e etnia. Seus métodos não excluíram o convívio inevitável com o branco, com quem sempre procuraram manter um relacionamento amistoso. A demonstração de respeito aos costumes e tradições alheias, o modelo de trajar-se copiado da população regional significam, mais do que submissão a um processo contínuo de aculturação, uma estratégia de auto-preservação. Desta forma, sob o traje que encobre diferenças profundas, os Guarani tentaram, embora nunca renegando sua condição de índio, com intolerância e intencional opacidade, resguardar-se de novas feridas (LADEIRA, 1994, p. 14).

Por outro lado, o contato permanente com a sociedade envolvente pode gerar questionamentos, sobretudo entre os mais jovens, quanto à sua condição de indígenas, principalmente por serem excluídos e

Espaço Ameríndio, Porto Alegre, v. 2, n. 1, p. 129-165, jan./jun. 2008. 
marginalizados pela sociedade nacional. A vontade de ser igual a todos os outros, de não serem tratados como diferentes e de serem aceitos pela sociedade envolvente também gera transformações na vivência da tradição e de alguma maneira transforma a vida social dentro da aldeia. Citando Litaiff (1996):

[...] Então o jovem questiona sua identidade. Por se envergonharem de serem "índios", procuram esconder sua origem, manipulando sua imagem, de forma a se aparentar ao padrão ocidental. O "índio" decide então ser como o "Juruá", bebendo sua bebida, ouvindo e dançando suas músicas, usando suas roupas, etc. Porém, mesmo assim não conseguem romper totalmente com sua identidade Guarani (LITAIFF, 1996, p. 77).

Essas transformações podem ser especuladas não como descaracterização da identidade indígena, mas como tentativa de serem reconhecidos como iguais mediante as oportunidades da sociedade nacional, ao perceberem o mundo com os olhos da sua cultura, eles desejam ser aceitos e respeitados enquanto cidadãos. Relatos de índios jovens demonstram que ao buscar um comportamento semelhante ao juruá, abre-se a possibilidade deles adentrarem em um mundo novo para freqüentar escolas, universidades, e buscar trabalho, já que a vida nas aldeias está cada dia mais difícil pela falta de terras suficientes para o sustento das famílias.

\section{A vinda para Karuguá}

A área indígena Karuguá está localizada dentro de uma Área de Proteção Ambiental (APA) e, de acordo com informações oficiais da Prefeitura de Piraquara, tem aproximadamente 25 alqueires, que foram cedidos de forma voluntária por um morador de Piraquara, o que foi confirmado por Hortêncio, o índio mais velho do grupo:

[...] o J. G., que mora ali em Piraquara, essa terra era toda dele. Então ele tem esse terra, né? Dele mesmo. Então vem lá do Mangueirinha, esposa, ele o Marcolino veio, e nós [parava] lá na casa do J. G., né? e depois [viemos] de lá de Mangueirinha daí o primeiro eu com

Espaço Ameríndio, Porto Alegre, v. 2, n. 1, p. 129-165, jan./jun. 2008. 
minha família que morou aqui [...] (HORTÊNCIO, 2007).

O cacique Marcolino e sua família foram os primeiros a chegar e iniciar as negociações políticas da área. Depois deles, vieram os demais moradores e suas famílias. Durante dois anos as famílias ficaram em uma chácara próxima à cidade de Piraquara, para depois serem transferidos para a aldeia do Karuguá. Silvio relatou que quando estavam nessa chácara a vida estava difícil e por isso, as mulheres saíam pelas casas da vizinhança pedindo comida e dinheiro. Segundo Hortêncio foi para acabar com a mendicância que os Mbyá-Guarani foram transferidos para uma nova área.

$\mathrm{Na}$ aldeia do Karuguá vivem hoje cerca de 65 indígenas MbyáGuarani e que apesar da maioria ser originária de Mangueirinha, há um número considerável de indivíduos que veio de outras aldeias do Espírito Santo, São Paulo, Santa Catarina, Rio Grande do Sul e Paraguai. A vinda do primeiro grupo para Piraquara aconteceu em 1999, de acordo com Silvio e Hortêncio, motivada pelo excesso das "intromissões dos brancos" e também pelo fato de que muitos indígenas utilizavam bebida alcoólica. Isso "atrapalhava" a boa convivência dentro da aldeia e causava frequentemente brigas e desentendimentos. De acordo com Litaiff, (1996, p. 74-78) o problema do alcoolismo existe em outras aldeias brasileiras, provocando conflitos entre os moradores, violência com não-indígenas, sobretudo quando os indígenas freqüentam bares ou festas nas cidades próximas às aldeias. Ainda de acordo com esse autor "os Mbyá são pacíficos, amáveis e muito retraídos diante de estranhos" (LITAIFF, 1996, p. 77), e quando se envolvem em brigas, normalmente estão embriagados. Outro motivo da vinda para o Karuguá relatado por Silvio, repousa no fato de que alguns indígenas foram atropelados na estrada que atravessa a aldeia de Mangueirinha, dentre eles, dois filhos do Cacique Marcolino. A perda violenta das crianças despertou no grupo a vontade de buscar outro lugar para viver.

Em sua etnografia na llha da Cotinga em Paranaguá, Bonamigo (2006, p. 60) encontrou motivos específicos para as migrações entre os Mbyá-Guarani, relacionados a conflitos com outros grupos indígenas que estão na mesma terra, a morte de parentes, conflitos entre lideranças internas ou ainda com o objetivo de visitas a pedido de

Espaço Ameríndio, Porto Alegre, v. 2, n. 1, p. 129-165, jan./jun. 2008. 
parentes ou de pajés de outras aldeias. Também em Karuguá o desejo de um novo lugar para viver trata da busca de uma solução para os conflitos vivenciados na antiga reserva. Conforme relata Silvio no trecho a seguir, quando questionado se acha bom morar no Karuguá: "[...] em Mangueirinha pior que aqui.... (silêncio) tinha a estrada no meio, Kaingáng ... e também por causa de católicos.... toda noite canta reza de católico [...]".

Para Silvio ainda que existam problemas sérios: "[...] na aldeia falta mais alimentos, mais trabalho, não tem trabalho para fazer, não tem nada, a gente tem vontade de procurar trabalho por aí, ganhar dinheirinho [...]", o Karuguá é um lugar melhor para morar quando comparado à Mangueirinha, pois ali eles conseguem praticar a reza todas as noites e se sentem mais reservados da sociedade envolvente.

\section{O jeito de ser Mbyá-Guarani - nhandereko - e a relação com Karuguá}

O significado de Nhandereko é bastante amplo, já que ele compreende a totalidade de perceber e viver os costumes e tradições Mbyá-Guarani de modo adequado para alcançar a "Terra Sem Mal". De acordo com Brand (1997, p. 25) "O modo de ser dos antigos ou nhandereko é o idioma geral dos Mbya-Guaranis que permite entender as suas coisas e o significado de suas palavras." Para que os MbyáGuarani possam viver de acordo com o nhandereko são necessárias algumas condições, como ambientes físicos adequados para a instalação de suas aldeias, alimentação apropriada para a preservação da sua identidade cultural e isolamento geográfico com relação à sociedade envolvente.

Meliá (1989) relata que o nhandereko possibilita que os MbyáGuarani mantenham sua identidade e sua diferenciação em relação aos demais grupos indígenas. A escolha da localização espacial da aldeia permite a manutenção da identidade étnica, e, ainda de acordo com esse autor, "sem tekoa não há nhandereko", ou seja, se a aldeia estiver localizada num espaço físico inadequado não há como viver de acordo com os costumes desses indígenas.

Espaço Ameríndio, Porto Alegre, v. 2, n. 1, p. 129-165, jan./jun. 2008. 
A espacialidade ideal para uma aldeia Mbyá-Guarani é que sua localização seja no mato, já que Nhanderu (principal divindade) fez o mato para que os Mbyá vivessem nele e dele retirassem sua sobrevivência, através da coleta de frutos, da caça, da pesca e da retirada de ervas medicinais. Nas aldeias Mbyá-Guarani há um consenso em preservar o meio ambiente, pois entendem que ao preservar a biodiversidade do seu território, eles podem viver à sua maneira.

O isolamento geográfico é uma possibilidade de distanciamento da sociedade nacional e de proteger o seu modo de vida da cultura ocidental. Segundo Ferreira (apud TEMPASS, 2005, p. 46), o isolamento geográfico também é preconizado pela religião Mbyá-Guarani, pois "Nhanderu quando criou os Mbyá e os 'brancos' deixou instruções para que eles vivessem separados". Contudo o crescimento das cidades e as disputas das terras indígenas com grupos da sociedade nacional têm sido obstáculos ao isolamento desejado pelos Mbyá. Na maioria dos casos, eles estão confinados em áreas muito pequenas, degradadas ambientalmente e a impossibilidade de retirarem seu sustento do mato tem levado os índios a buscarem assistência na sociedade envolvente. Esse convívio com os juruá é muitas vezes percebido, especialmente entre os mais velhos, como algo danoso à cultura guarani, pois decorre em mudanças no comportamento tradicional e descumprimento do nhadereko.

O isolamento geográfico faz com que os Mbyá-Guarani se percebam como Guarani puros, que vivem de acordo com o que Nhanderu preconizou, em oposição aos grupos Guarani Ñandevá e Kaiová e a outros grupos indígenas, que vivem em desacordo com o nhandereko, pois utilizam bebida alcoólica, fumam cigarro, freqüentam bailes, derrubam a mata para vender madeira (TEMPASS, 2005; LITAIFF, 1996). A percepção de pureza da cultura pode ser vista através da aproximação conflituosa com os hábitos da sociedade envolvente, que são incorporados aos hábitos tradicionais, dificultando a vivência do nhandereko e distanciando os Mbyá-Guarani de Nhanderu.

Assim, a incorporação de novas práticas de vida provoca transformações na identidade de grupo, que passa a se perceber como igual a todos os outros, o que não é desejado pelos Mbyá-Guarani. Neste sentido é que o isolamento geográfico é imprescindível para a

Espaço Ameríndio, Porto Alegre, v. 2, n. 1, p. 129-165, jan./jun. 2008. 
manutenção da sociedade Mbyá-Guarani. O recurso do distanciamento possibilita resistir às transformações culturais, e reforçar o significado de sua etnicidade mantendo vivas sua língua, religião e organização social.

Para que haja uma plena vivência do nhandereko é necessário que os Mbyá-Guarani alimentem-se de acordo com suas tradições, para que possam manter a leveza dos seus corpos e assim, alcançarem a vida eterna e chegarem a Terra Sem Mal. A leveza do corpo favorece o movimentar-se, a participação nos rituais religiosos, dançando e cantando seus ritos sagrados, atitudes que complementam seu jeito de ser dentro da aldeia e favorecem que os Mbyá-Guarani flutuem sobre o oceano para chegarem a Terra Sem Mal, já que ela encontra-se além do mar (BONAMIGO, 2006; TEMPASS, 2005).

A Terra Sem Mal é o local que todo Mbyá-Guarani almeja chegar e procura durante sua vida terrena, representando um paraíso na terra. $\mathrm{Na}$ Terra Sem Mal há fartura, os alimentos são conseguidos sem muitos esforços e os indígenas serão sempre jovens, vivendo sem as dificuldades e os sofrimentos que enfrentam aqui na terra. Para que alcancem a Terra Sem Mal, eles devem levar uma vida exemplar na terra, vivendo de acordo com o nhandereko, para alcançarem a perfeição. Eles podem obter a entrada na Terra Sem Mal depois de mortos ou ainda em vida. Para chegarem a Terra Sem Mal vivos, faz-se necessário que respeitem algumas regras, dentre elas as regras alimentares, que devem promover a leveza e a limpeza do corpo, para que possam ascender a Terra Sem Mal depois de alcançarem a perfeição do jeito de ser MbyáGuarani. A localização da Terra Sem Mal seria a leste, o que explicaria a migração guarani em direção ao mar, na esperança de alcançarem o paraíso (TEMPASS, 2005; OLIVEIRA, 2006).

Assim, viver de acordo com o jeito de ser Mbyá-Guarani requer que os indígenas tenham um espaço geográfico que possibilite a comunhão deles com a natureza, no qual possam plantar suas roças, coletar frutos, sementes e ervas no mato, e praticar a pesca e caça e que asseguraria a aproximação deles com a Terra Sem Mal, elemento essencial à manutenção das tradições étnicas Guarani.

Espaço Ameríndio, Porto Alegre, v. 2, n. 1, p. 129-165, jan./jun. 2008. 
Os hábitos alimentares em comunidades indígenas e a segurança alimentar e nutricional no contexto do Direito Humano à Alimentação Adequada

Há muito tempo, as comunidades indígenas vêm passando por um acelerado e crescente processo de mudanças sócio-culturais provocado pelas inevitáveis relações de contato interétnico com a sociedade envolvente. Todas as mudanças que vêm ocorrendo repercutem diretamente sobre os hábitos alimentares e, conseqüentemente, refletem sobre o estado nutricional desses grupos. O abandono das atividades básicas de subsistência beneficia a monotonia alimentar e aumenta a dependência com relação aos produtos industrializados e à assistência alimentar por parte do Estado. Em decorrência disso as comunidades indígenas podem ser consideradas como grupos de risco para a ocorrência de carências nutricionais, como desnutrição energético-protéica, anemias, hipovitaminoses, que estão associadas a elevadas prevalências de doenças infecto-parasitárias, comprometendo ainda mais a saúde dessa população (COIMBRA JR e SANTOS, 1991; GUGELMIN e SANTOS, 2001; LEITE et al, 2006).

Fávaro et al, em estudo publicado em 2007, confirma o disposto acima, como pode ser observado no trecho a seguir:

No Brasil, os povos indígenas estão expostos a transformações ambientais e sócio-econômicas, que os colocam em situação de alta vulnerabilidade frente a problemas de ordem alimentar e nutricional. Nesse sentido, estudos pontuais realizados em comunidades indígenas revelam a fragilidade de muitos povos frente às conseqüências das carências alimentares, como a elevada prevalência de nanismo nutricional em crianças menores de 5 anos de idade, também favorecida por precárias condições de saneamento, entre outros determinantes (FÁVARO et al, 2007, p. 786).

A maioria das comunidades indígenas está mergulhada num ambiente propício à insegurança alimentar e nutricional, ocasionado pela falta de acesso aos alimentos em caráter permanente, pela falta de terras para o cultivo dos alimentos que são culturalmente importantes, e pela substituição dos hábitos alimentares tradicionais incorporando

Espaço Ameríndio, Porto Alegre, v. 2, n. 1, p. 129-165, jan./jun. 2008. 
práticas alimentares da sociedade envolvente, principalmente com relação aos alimentos industrializados.

O direito à alimentação é um direito humano básico, reconhecido internacionalmente: o artigo 25 , inciso $1^{\circ}$, da Declaração Universal dos Direitos Humanos (1948), institui que "todos têm direito a um padrão de vida adequado, de saúde e bem-estar de si próprio e de sua família, incluindo alimentação". A negação ao acesso a uma alimentação adequada atenta contra o direito primordial do ser humano: o direito à vida (VALENTE, 1997; GRACIA, 2005).

Todavia, esse direito não se restringe apenas à mera ingestão de nutrientes por meio dos alimentos, mas incorpora em um sentido mais amplo, a questão da cultura e da sustentabilidade.

O Direito Humano à Alimentação passa pelo direito de acesso aos recursos e meios para produzir ou adquirir os alimentos seguros e saudáveis que possibilitem uma alimentação de acordo com os hábitos e as práticas alimentares de sua cultura, de sua região ou de sua. origem étnica (VALENTE, 1997, p. 21 - grifos das autoras).

No Karuguá não existe a possibilidade de produção dos alimentos para a manutenção da vida, tampouco a alimentação deles reflete os aspectos relativos à segurança alimentar e nutricional relacionados à conservação de hábitos alimentares tradicionais.

Por Segurança Alimentar e Nutricional (SAN) entende-se a realização do direito de todos os indivíduos ao acesso adequado e estável a alimentos com qualidade, sem afetar a realização de outras necessidades humanas. Deve estar pautado em práticas alimentares promotoras de saúde, aceitas culturalmente e sustentáveis do ponto de vista social, econômico e ambiental (MALUF, 2007).

O conceito de SAN contempla as várias faces do direito humano à alimentação como as condições ambientais para a produção, a relação cultural que permeia a alimentação e as práticas de saúde dos povos. $O$ conceito de cultura imbricado na SAN está relacionado à grande diversidade étnica presente no Brasil. Dessa forma, para a concretização da SAN, além do acesso às quantidades suficientes de nutrientes para a manutenção da vida, a alimentação enquanto um fenômeno social deve

Espaço Ameríndio, Porto Alegre, v. 2, n. 1, p. 129-165, jan./jun. 2008. 
estar assegurada como meio para a realização do desenvolvimento pleno do indivíduo (FREITAS e PENA, 2007).

A concretização da SAN no país, com garantias às pessoas de estarem livre da fome necessita que a abordagem das políticas de SAN aproxime-se do conceito de Direito Humano a Alimentação Adequada (DHAA).

o direito à alimentação adequada é um direito humano inerente a todas as pessoas de ter acesso regular, permanente e irrestrito, quer diretamente ou por meio de aquisições financeiras, a alimentos seguros e saudáveis, em quantidade e qualidade adequadas e suficientes, correspondentes às tradições culturais do seu povo e que garanta uma vida livre do medo, digna e plena nas dimensões física e mental, individual e coletiva (ABRANDH, 2007a, p. 9).

O DHAA engloba duas dimensões: o direito de estar livre da fome e da má nutrição e o direito à alimentação adequada. Alimentação adequada não significa somente alimentação suficiente em termos de nutrientes, mas refere-se aquilo que é considerado comida para determinado grupo étnico. O DHAA alia a concepção de estado físico ideal (estado de segurança alimentar e nutricional) aos princípios de direitos humanos tais como dignidade, igualdade, participação, não discriminação, entre outros. A obrigação de respeitar consiste na garantia de que o Estado não pode adotar medidas que privem indivíduos ou grupos de buscar sua alimentação; a obrigação de proteger relaciona-se à preocupação que o Estado deve ter com relação à ação de terceiros que possam interferir na realização do DHAA; a obrigação de promover significa que devem ser criadas condições para efetivação do DHAA e a de prover, que deve ser utilizada em casos extremos, refere-se à doação de alimentos em caráter emergencial, a grupos que se encontram incapazes de garantir sua própria alimentação, sobretudo grupos vulneráveis, como minorias étnicas ou povos indígenas (ABRANDH, 2007b).

A concretização da SAN e do DHAA deve passar necessariamente pelo respeito à cultura indígena. Para que esse direito seja garantido, obviamente faz-se necessário a devolução das terras tradicionalmente ocupadas pelos indígenas além do acesso à educação e saúde.

Espaço Ameríndio, Porto Alegre, v. 2, n. 1, p. 129-165, jan./jun. 2008. 


\section{A alimentação em Karuguá: tradição versus possibilidade}

A alimentação tradicional dos indígenas, de maneira geral, é baseada em produtos por eles coletados ou cultivados em roças, servindo como um dos critérios de diferenciação étnica. Entre os MbyáGuarani, através do plantio, da caça, da pesca e da coleta de frutos, eles obtêm seus alimentos tradicionais e ocorre a manutenção das regras alimentares, que são importantes para que eles se aproximem de Nhanderu (TEMPASS, 2005).

A alimentação tradicional baseia-se, principalmente, no milho e na mandioca. Outros alimentos que também fazem parte da dieta são a batata-doce roxa, a abóbora, a melancia, o feijão, o amendoim, a banana, a cana-de-açúcar e o abacaxi (HECKLER, 2006). Normalmente os Mbyá-Guarani buscam habitar áreas com condições ambientais que favoreçam a manutenção dos seus hábitos alimentares tradicionais e sua subsistência (FELIPIM, 2001). Em sua etnografia Tempass (2005) demonstrou que os alimentos tradicionais cultivados pelos MbyáGuarani em suas roças são considerados bons e recomendados. O que for produzido de modo diferente é percebido como ruim e deve ser evitado, referindo-se aos alimentos cultivados com sementes dos juruá ou produzidos por juruá.

O cultivo de roças entre os Mbyá-Guarani favorece sua aproximação com a Terra Sem Mal, pois através da agricultura eles obtêm o principal alimento da cultura Mbyá-Guarani: o milho avati eteí - espécie de milho tradicional que tem espigas menores e grãos adocicados e macios. O milho é utilizado na cerimônia do nimongarai ou batismo, a cerimônia de nomeação mais importante entre os MbyáGuarani que acontece no mês de janeiro, na mesma época da colheita do milho. No batismo, além do milho é utilizado o mel coletado na mata.

Os Mbyá-Guarani possuem dois nomes, um em português, que é dado pelos pais no momento do nascimento e outro, o nome Guarani, que é revelado ao pajé por Nhanderu. A criança só pode ser batizada depois que começar a falar. $\mathrm{O}$ nome revelado ao pajé está relacionado

Espaço Ameríndio, Porto Alegre, v. 2, n. 1, p. 129-165, jan./jun. 2008. 
com o deus que enviou a alma do Mbyá-Guarani para a terra, declarando a origem do espírito, isto é, se ele veio da terra, do céu, do mar. A cerimônia da nomeação garante ao Mbyá-Guarani uma boa vivência na terra e informa de que maneira ele deve conduzir sua vida para alcançar a Terra Sem Mal (LITAIFF, 1996).

Desde pequenas as crianças devem ser ensinadas que se alimentar em excesso as afasta de Nhanderu. Comer de forma moderada e seguindo as restrições alimentares promovem a vivência do jeito de ser Mbyá-Guarani. Além disso, quando os indígenas se alimentam eles devem relembrar os significados tradicionais das comidas. Por exemplo, o milho deve ser comido com alegria, pois ele traz o nome; comer batata-doce relembra os antepassados (BONAMIGO, 2006).

Através do cultivo do milho, há a possibilidade de preparação de alguns alimentos e bebidas. O milho verde é preparado assado, que segundo Sílvio, acentua seu sabor adocicado. Do milho verde é feito o Kaguijy, bebida fermentada que é utilizada no batismo. Quando o milho está seco, é preparado o fubá. O fubá é utilizado para o preparo do mbojape, um bolo de milho feito com água e fubá, que é assado entre as brasas do fogo de chão. Esse alimento é muito importante no batismo, sendo oferecido a Nhanderu pelos pais das meninas. No caso dos meninos, o alimento oferecido a Nhanderu é o mel, que deve vir do mato (BONAMIGO, 2006; TEMPASS, 2005).

Dessa maneira, o cultivo do milho avati eteí é indispensável para a manutenção das tradições Mbyá-Guarani. Garlet (apud BONAMIGO, 2006, p. 113) explica que:

O milho além de ser o elo que une dois mundos introduz a pessoa na sociedade. Sem ele o Mbyá não recebe um nome, não se torna uma pessoa e não se inscreve no círculo de relações sociais, não existe (GARLET apud BONAMIGO, 2006, p. 113).

Em conversa com os moradores do Karuguá, houve o relato da importância do milho avati eteí, que eles chamam de "milho guarani". Júlio fala de duas comemorações que fazem parte do calendário de festas da aldeia, a Festa da Primavera e o nimongarai (batismo): "[...] A maior comemoração aqui é a da Primavera e a crisma das crianças,

Espaço Ameríndio, Porto Alegre, v. 2, n. 1, p. 129-165, jan./jun. 2008. 
quando batiza, coloca o nome indígena [...]". Quando indagado sobre o significado da Festa da Primavera, ele esclarece: "[...] por causa que vai vim coisa nova, vai florescer, vai entrar a paisagem, a natureza [...]". Quando perguntado a Júlio sobre quais alimentos são consumidos na Festa da Primavera ele nos respondeu: "[...] comemos frutas, como maçã, banana ... que é doação ... aqui não tem [...]". Com relação ao batismo e a presença do milho guarani na cerimônia, que não é plantado na aldeia, mas necessário para que o pajé consiga receber de Nhanderu o nome destinado à criança, Julio esclareceu: "[...] o milho avati eteí para o batismo a gente buscamo, compramo, tem também a batata-doce roxa... nós busca de uma aldeia em outra [...]".

Sílvio nos contou que sente muita saudade de comer o milho verde que comia em Mangueirinha. Ele diz: "[...] lá em Mangueirinha comia milho verde... tira a palha e coloca direto no fogo, fica vermelhinho ...". Quando questionado se na cerimônia do batismo podia ser utilizado o milho não guarani, Silvio ficou em silêncio. Segundo Bonamigo (2006), o batismo acontecia antigamente durante a festa do milho, na qual havia abundância de alimentos da roça da aldeia, contudo, hoje, há a inclusão do fubá doado por não-indígenas que se mistura ao milho guarani. A aceitação de alimentos não tradicionais em uma importante cerimônia Mbyá-Guarani pode ser investigada no sentido da incorporação e da mistura entre os elementos do interior e exterior da cultura para a manutenção do ritual. No Karuguá o rito do batismo depende da substituição de alimentos tradicionais por outros que estejam disponíveis evitando assim o desaparecimento dos costumes dos seus ancestrais. Não havendo o milho, não há o batismo, a nomeação, pois Nhanderu se releva através do milho ou do fubá, por isso eles aceitam utilizar o fubá doado no batismo, como forma de resguardar as tradições, já que o milho fortalece a comunidade e proporciona a vivência do nhandereko, mesmo que isso pareça contraditório, já que para viver o nhandereko é necessário o cumprimento das regras alimentares, entre elas evitar o consumo de alimentos juruá.

A grande dificuldade de manutenção da alimentação tradicional dos indígenas e a conseqüente insegurança alimentar não é específica do Karuguá. Outros estudos mostram que a insegurança alimentar e

Espaço Ameríndio, Porto Alegre, v. 2, n. 1, p. 129-165, jan./jun. 2008. 
nutricional está presente no cotidiano de muitas aldeias indígenas no Brasil. Bonamigo (2006) mostra que na llha da Cotinga/PR existem inúmeras dificuldades no acesso à alimentação adequada. A roça não pode ser cultivada, pois a terra é arenosa e as plantas não conseguem nascer. Por outro lado, a venda de artesanato não produz rendimentos suficientes para a compra de alimentos e como o órgão tutor responsável pelo repasse das cestas básicas é muito lento, os indígenas mendigam em portas de restaurantes, e, até mesmo, buscam restos de comida nas lixeiras próximas ao mercado municipal da cidade (BONAMIGO, 2006).

Diehl (2001) encontrou em uma comunidade Kaingáng em Santa Catarina mais um exemplo da dificuldade de acesso aos alimentos. A quantidade de terra é insuficiente para o plantio de roças, o meio ambiente está degradado, com raras espécies de mata nativa que não garantem a subsistência da comunidade através do plantio, coleta ou caça. A dependência quase que exclusiva dos indígenas dos favores do comércio local de alimentos tem favorecido a desnutrição energéticoprotéica e os agravos à saúde dela decorrentes, especialmente entre as crianças. Em outro estudo no Mato Grosso do Sul, Ribas et al (2001) também encontraram indígenas em dificuldades com relação à alimentação, pois as atividades tradicionais que garantiriam aos indígenas acesso aos alimentos são praticadas com limitações, devido ao tamanho da reserva.

A entrada do dinheiro no Karuguá concretiza-se pelas diversas estratégias de sobrevivência adotadas pelos indígenas. Vendem artesanato aos turistas que visitam a aldeia, cobram pelas apresentações na cidade, ou recebem cestas-básicas de um órgão da Secretaria Estadual de Assistência Social em troca de animais esculpidos em pedaços de madeira. Além de receberem doações de alimentos e roupas, alguns índios são beneficiários do INSS e outras famílias participam do Programa do Governo Federal, Bolsa-Família.

Quando os Mbyá-Guarani recebem alguma quantia em dinheiro eles procuram comprar alimentos. Os alimentos que fazem parte da dieta cotidiana são os alimentos industrializados, que são doados ou adquiridos no comércio local. Quando perguntamos a Hortêncio quais alimentos são consumidos por ele e sua família, ele respondeu, irritado:

Espaço Ameríndio, Porto Alegre, v. 2, n. 1, p. 129-165, jan./jun. 2008. 
“[...] nós come o que dá ... por que que quer saber? Comemo feijão, arroz, macarrão, não tem outra comida [...]". Quando questionado se tinha o que comer na mata, novamente ele responde bem irritado: "[...] tem tudo ... (silêncio) antigamente não era assim, agora nós come o que dá [...].

Conversando com Cleuza, esposa de Júlio, em outro dia, ela também descreveu a alimentação do dia-a-dia de sua família:

[...] eu faço comida de branco e comida nossa, que eu gosto também ... a comida do dia-a-dia é igual a de vocês: arroz, feijão, todo mundo come isso, mas a comida que meu povo gosta mais de comer é o peixe, é o macaco do mato, é a polenta, o milho e a mandioca [...] (CLEUZA, 2007).

Ao ser indagada sobre não poder cultivar a roça de mandioca nem de milho no Karuguá ela respondeu que não tem outro jeito senão comprar. Na mesma conversa ela disse que o que gosta de fazer de comida tradicional é:

[...] a mais que a gente gosta de fazer, tipo assim, é o milho... a gente torra bem torrado, soca no pilão, faz aquele fubá! Come com uma caça ou peixe, ou com frango caipira e faz um viradinho de feijão e come ... também faz canjica, que é milho, não vai esses negócios de vocês, que põe leite, coco, vai só o milho e o açúcar, essa é a nossa canjica [...] (CLEUZA, 2007).

A preparação de comidas tradicionais acontece quando existe a disponibilidade dos alimentos tradicionais e principalmente em ocasiões especiais. No primeiro dia que fomos à aldeia, observamos que em algumas casas estava sendo preparado o almoço, e que, os alimentos eram os mesmos alimentos da dieta ocidental: frango, arroz, feijão e os temperos eram sal e óleo, com a diferença de que ao invés de serem preparados no fogão a gás, todos estavam sendo preparados no fogo de chão. Entre as bebidas há a presença constante do chimarrão, que é bebido durante o dia todo, inclusive no verão, conforme falou Sílvio. A erva-mate serve para purificar o corpo,

[...] mas sua principal finalidade é aumentar a resistência à fadiga e amenizar a fome, possibilitando

Espaço Ameríndio, Porto Alegre, v. 2, n. 1, p. 129-165, jan./jun. 2008. 
que os Mbyá-Guarani, em geral, comam menos e, assim, tornem seus corpos perfeitos para alcançar a Terra Sem Mal (TEMPASS, 2005, p. 123).

$\mathrm{Na}$ casa que fomos convidados a entrar havia no quarto três latas de leite em pó. Perguntamos a Sílvio se as crianças bebem leite e ele respondeu negativamente, pois no Karuguá "não pode ter vaca, "eles" [referindo-se ao IBAMA] não deixam e também não deixam criar galinha". O consumo de proteínas é restrito à carne de frango, e alimentos como frutas e vegetais são consumidos quando doados ou comprados. Capelli e Koifman (2001) e Ribas et al (2001) constataram quadros semelhantes em uma aldeia no Pará e outra do Mato Grosso do Sul, respectivamente. Eles observaram que os alimentos industrializados fazem parte da dieta dos indígenas e que o óleo de soja, o sal, o açúcar, o café, o pão e o biscoito, o macarrão, além dos refrigerantes estão entre os gêneros alimentícios mais comprados. Estes estudos têm demonstrado um certo padrão na incorporação das dietas tradicionais dos alimentos da sociedade envolvente.

A observação da alimentação atual, que é a alimentação possível na aldeia, possibilita a compreensão de que pela falta de recursos naturais suficientes para que os Mbyá-Guarani do Karuguá cultivem suas roças, coletem alimentos no mato, eles buscam alternativas de consumo de outros alimentos, como os industrializados, apesar de saberem que esses alimentos não favorecem a leveza dos seus corpos e os distanciam de Nhanderu. Esses alimentos não são considerados alimentos Mbyá-Guarani e são percebidos por eles como alimentos perigosos, pois contém ingredientes desconhecidos (TEMPASS, 2005).

Com relação à alimentação escolar, os gêneros que a compõem são basicamente industrializados, alheios à cultura Mbyá-Guarani, e, portanto fatores que impedem a concretização da SAN desse povo. Através da observação dos alimentos servidos no âmbito escolar, notase a transformação no paladar das crianças e nas suas preferências alimentares. À medida que as crianças recebem alimentos da cultura ocidental, como bolachas, refrescos, pudins, enlatados, sopas em pó, etc., há uma incorporação desses alimentos no cotidiano dessas crianças. Pela falta dos alimentos tradicionais Mbyá-Guarani, existe a facilidade de substituição dessas comidas pelas que estão ao alcance

Espaço Ameríndio, Porto Alegre, v. 2, n. 1, p. 129-165, jan./jun. 2008. 
das famílias, já que quando há falta de alimentos e a fome está presente diminui a possibilidade da escolha. No entanto, à medida que os alimentos industrializados são incorporados à dieta habitual, eles passam a fazer parte do cotidiano e, por serem muito saborosos, eles acabam sendo consumidos sempre que possível. Tempass (2005), também encontrou entre os Mbyá-Guarani de duas aldeias no Rio Grande do Sul, essa incorporação de alimentos não-tradicionais à alimentação dos indígenas com quem trabalhou. Ele relata que "muitos [referindo-se aos indígenas] chegam a afirmar que sua comida preferida é o arroz, o macarrão e a maionese" (TEMPASS, 2005). No entanto, ele observou que apesar dos indígenas preferirem alimentos juruá, eles justificam que os ingredientes são juruá, mas o modo de preparo é Mbyá-Guarani.

O cardápio da merenda escolar não é um cardápio que considera as diferenças étnicas e culturais entre os indígenas e os juruá, mas possibilita que as crianças que freqüentam a escola façam alguma refeição durante o dia. Observando a hora do lanche, percebemos que as crianças comem, e repetem o lanche com satisfação.

Em um dos passeios que fizemos junto às crianças até o campinho de futebol, observamos que enquanto caminhávamos para voltar à aldeia, elas procuravam no mato frutas que pudessem coletar para comer. Durante a caminhada que durou cerca de quinze minutos, elas foram coletando, com a ajuda do professor, limões pequeninos, que foram sendo apanhados do limoeiro, descascados como se fossem mexerica, e consumidos pelas crianças. A cena do passeio no contexto cotidiano da fome e das dificuldades que as crianças guarani experimentam para comer despertou à reflexão sobre a cultura milenar dos indígenas em seu papel de coletores, na forma como tradicionalmente gostariam de viver em sua relação com a natureza.

A dificuldade de obtenção de alimentos básicos para a manutenção da cultura Mbyá-Guarani no Karuguá ocorre, principalmente por que a aldeia encontra-se numa APA, impossibilitando que os moradores da aldeia produzam seu próprio alimento. De modo geral, as observações realizadas em Karuguá com relação às condições de vida, à alimentação, à dificuldade de acesso aos alimentos e ao modo de vida Mbyá-Guarani, revelam a impossibilidade

Espaço Ameríndio, Porto Alegre, v. 2, n. 1, p. 129-165, jan./jun. 2008. 
dos indígenas de viverem de acordo com os ensinamentos de seus ancestrais. O cultivo sustentável de roças de acordo com o conhecimento tradicional guarani proporcionaria a conservação de seus hábitos alimentares e de suas práticas tradicionais de viver de acordo com seu nhandereko. Nesta perspectiva haveria a garantiria do seu direito à alimentação adequada, com direito ao consumo de uma dieta variada e equilibrada nutricionalmente assegurando a segurança alimentar e nutricional indígena.

\section{De quem é a terra?}

O Estatuto do Índio é a Lei Federal 6001, de 19 de dezembro de 1973, que regula a situação jurídica dos indígenas e das comunidades indígenas, com o objetivo de preservação da sua cultura e promoção de sua integração à sociedade nacional (FUNAI, 2007). O estatuto seguia um princípio estabelecido pelo Código Civil Brasileiro de 1916: de que os indígenas, sendo "relativamente capazes", deveriam ser tutelados por um órgão indigenista estatal (de 1910 a 1967, o Serviço de Proteção ao Índio/SPI); atualmente a Fundação Nacional do Índio/(Funai), até que eles estivessem integrados à sociedade nacional, havendo por isso, a necessidade de revisões. Essas revisões começaram a acontecer na década de 1990 e segundo Litaiff e Darella (2000, p. 38), o Estatuto do Índio e das Comunidades Indígenas ainda não foi aprovado.

De acordo com o Estatuto do Índio, artigos 23 e 24, considera-se como de pose dos grupos indígenas, a ocupação efetiva da terra onde habitam ou exercem atividade indispensável à sua subsistência ou economicamente útil, sendo-lhe garantido o uso das riquezas naturais, incluindo o uso dos mananciais e das águas dos trechos das vias fluviais compreendidos nas terras ocupadas, além do exercício da caça e pesca nas áreas por ele habitadas (BRASIL, 1973)

A garantia dos indígenas à terra fica explícita no artigo 26 , do Estatuto do Índio, como transcrito abaixo:

A União poderá estabelecer, em qualquer parte do território nacional, áreas destinadas à posse $\mathrm{e}$ ocupação pelos indígenas, onde possam viver e obter 
meios de subsistência com direito ao usufruto e utilização das riquezas naturais dos bens nela existentes, respeitadas as restrições legais (BRASIL, 1973).

De acordo com o artigo acima transcrito, o Estado poderá destinar qualquer área do território nacional para as comunidades indígenas, e essas áreas deverão oferecer a esses povos garantia de subsistência. Entretanto, há uma enorme distância entre o que está previsto em lei e a sua aplicação, principalmente em se tratando de minorias étnicas excluídas (HECK e PREZIA, 1999). O Estatuto do Índio, em sua criação, estabeleceu que as terras ocupadas por grupos indígenas deveriam ser demarcadas no prazo de cinco anos, entretanto isso não ocorreu devido a pressões políticas e econômicas contrárias à demarcação.

As políticas que foram adotadas desde essa época até a promulgação da Constituição de 1988, foram políticas que pretendiam incorporar os indígenas à sociedade nacional, o que gerou muitos conflitos entre os interesses indígenas pela manutenção de suas terras e conseqüentemente de seus costumes e alguns segmentos da sociedade brasileira, que desejavam promover projetos de "crescimento e expansão da sociedade nacional" (HELM, 1987, p. 56). A disputa pelas áreas indígenas, facilitadas pela dificuldade e demora da demarcação dessas terras, traz conseqüências graves para essa população, como dificuldade de acesso aos serviços básico de saúde, falta de alimentos, falta de saneamento básico, fatores estes enormemente relacionados à morbimortalidade infantil indígena.

A Constituição Federal de 1988, no seu capítulo VIII, que dispõe sobre os indígenas, em seu artigo 231 , reconhece a diversidade sóciocultural existente no Brasil, estabelecendo que:

São reconhecidos aos indígenas sua organização social, costumes, línguas, crenças e tradições, e os direitos originários sobre as terras que tradicionalmente ocupam, competindo à União demarcá-las, proteger e fazer respeitar todos os seus bens.

$\S 10$ - São terras tradicionalmente ocupadas pelos indígenas as por eles habitadas em caráter permanente, as utilizadas para suas atividades produtivas, as imprescindíveis à preservação dos recursos ambientais necessários a seu bem-estar e as necessárias a sua reprodução física e cultural, segundo

Espaço Ameríndio, Porto Alegre, v. 2, n. 1, p. 129-165, jan./jun. 2008. 
seus usos, costumes e tradições.

$\S 20$ - As terras tradicionalmente ocupadas pelos indígenas destinam-se a sua posse permanente, cabendo-Ihes o usufruto exclusivo das riquezas do solo, dos rios e dos lagos nelas existentes (BRASIL, 1988).

Somente a partir da Constituição do Brasil, o Estado Brasileiro reconheceu que os povos indígenas necessitam de terras regulamentadas para sua sobrevivência e de sua cultura, e que podem retirar dessa terra as riquezas que necessitarem para viver. Entretanto, Litaiff e Darella (2000, p. 35-36), citando o jurista Carlos Frederico Marés de Souza Filho, que afirma que a terra destinada pelos governos aos povos indígenas, desde os tempos do Brasil Colônia, representa uma pequenina parte do território do qual eles eram os donos legítimos, chamando essas terras de Reserva Indígena, o que significa, segundo o jurista "nada mais do que uma porção de terra pública separada (reservada) de uma gleba maior (...)" (LITAIFF e DARELLA, 2000, p. 36). Isso não quer dizer que os direitos dos indígenas sobre as terras ocupadas estão reconhecidos e são respeitados, mas que há, efetivamente, a separação de um pedaço de terra destinada a eles, da qual eles precisam retirar o sustento do grupo. As áreas destinadas às reservas indígenas são áreas onde há degradação dos ecossistemas ou são terras disputadas por sua enorme biodiversidade, como é o caso da Amazônia. $\mathrm{O}$ direito indígena sobre as terras tradicionalmente ocupadas não depende somente de demarcação, já que ela é uma providência administrativa, por ele ser um direito originário, mas sobretudo depende do reconhecimento pela sociedade que isso é um direito legítimo, anterior à constituição do Estado.

Mas qual é o significado da terra para os povos indígenas? A terra para eles significa a vida. Retiram seu alimento, remédios, madeira (HECK e PREZIA, 1999). Ela faz parte do universo religioso e, em especial para os Mbyá-Guarani. Possibilita a vivência do seu jeito de ser MbyáGuarani e a manutenção das redes de parentesco. Através da terra, eles geram cultura, vida, valores, história, narram sua origem e explicam o mundo através dos seus mitos. Desse modo, segundo Heck e Prezia (1999, p. 43) "é impossível imaginar um povo indígena sem terra". 


\title{
A aldeia de Karuguá dentro de uma Área de Proteção Ambiental (APA)
}

O Decreto Estadual 1754, de 06 de maio de 1996, instituiu a Área de Proteção Ambiental no manancial da bacia hidrográfica do rio Piraquara, denominada APA Estadual do Piraquara, localizada no município de Piraquara, cuja área aproxima-se de 8.881 hectares. Os objetivos da APA Estadual do Piraquara são a proteção e a conservação da qualidade ambiental e dos sistemas naturais ali existentes, principalmente a qualidade e quantidade da água que se destina ao abastecimento público.

Com a criação dessa APA, de acordo com a referida Lei acima citada, em seu artigo $5^{\circ}$, ficam proibidos ou restringidos:

\begin{abstract}
(...) II - O exercício de atividades capazes de provocar erosão das terras ou assoreamento de coleções hídricas;

III - A realização de obras de terraplanagem e a abertura de canais, quando essas iniciativas importarem em sensível alteração das condições ecológicas locais;

IV - O desenvolvimento de atividades minerárias capazes de afetar ou colocar em risco a qualidade da água do manancial;

V - O uso de agrotóxicos e outros biocidas em desacordo com as normas ou recomendações instituídas no Plano de Manejo (PARANÁ, 1996).
\end{abstract}

Após a implementação da Lei Estadual Nº 1754, de 06/5/1996, para regularização dos mananciais no Estado do Paraná, foi decretada no cenário nacional a Lei $\mathrm{N}^{\circ}$ 9985, de 18 de julho de 2000, que instituiu o Sistema Nacional de Unidades de Conservação, definindo como unidade de conservação um espaço territorial e seus recursos ambientais, incluindo as águas jurisdicionais, legalmente instituídas pelo Poder Público, com objetivos de conservação e limites definidos, ao qual se aplicam garantias adequadas de proteção. Nessa Lei surge o conceito de área de proteção ambiental (APA) de uso sustentável, sendo definida como:

A Área de Proteção Ambiental é uma área em geral extensa, com um certo grau de ocupação humana, 
dotada de atributos abióticos, bióticos, estéticos ou culturais especialmente importantes para a qualidade de vida e o bem-estar das populações humanas, e tem como objetivos básicos proteger a diversidade biológica, disciplinar o processo de ocupação e assegurar a sustentabilidade do uso dos recursos naturais.

$\S 10$ A Área de Proteção Ambiental é constituída por terras públicas ou privadas (BRASIL, 2000).

Nessa mesma lei, o artigo $5^{\circ}$, parágrafo $X$, garante às populações tradicionais estabelecidas dentro de uma unidade de conservação o uso dos recursos naturais para sua subsistência, desde que isso não traga conseqüências indesejáveis ao meio ambiente, como consta no artigo 23 , § 2, que proíbe "o uso de espécies localmente ameaçadas de extinção ou de práticas que danifiquem os seus habitats e práticas ou atividades que impeçam a regeneração natural dos ecossistemas" (BRASIL, 2000).

Dentro desse contexto de proteção, preservação e recuperação do meio ambiente, os Mbyá-Guarani foram trazidos à aldeia do Karuguá em 1999. Entretanto a área foi reconhecida somente este ano, através do Decreto Municipal No 2941/2007, sob a denominação de Espaço Etno Bio Diverso M'bya Guarani - Aldeia Araçá-í que não garantiu a demarcação da terra indígena, possivelmente pela presença da represa que abastece água para Curitiba e Região Metropolitana. A constituição da APA impede a utilização das águas e do solo pelos Mbyá a despeito dos modos tradicionalmente sustentáveis dos indígenas no manejo dos recursos naturais. Para Ladeira (2001, p. 219):

Os princípios de desenvolvimento que implicam em ordenamento territorial não deveriam considerar a natureza e sua dinâmica só como recursos. Nesse sentido, o conhecimento, o manejo e o modo de ocupação das comunidades indígenas devem ser as referências iniciais para se ordenar as ocupações nas regiões e no entorno de suas áreas.

As restrições de utilização da área pelos Mbyá-Guarani afetam, sobretudo, seu DHAA, já que as práticas tradicionais de acesso aos alimentos, como cultivo de roças, caça de animais silvestres e pesca são proibidas.

Espaço Ameríndio, Porto Alegre, v. 2, n. 1, p. 129-165, jan./jun. 2008. 
De maneira geral o Decreto Municipal No 2941/2007, garante ao grupo Mbyá-Guarani a implantação da área indígena, no entanto em nenhum artigo do referido decreto consta que a área será demarcada. Conforme explicam Heck e Prezia (1999, p. 58) a demarcação de uma área indígena é lenta e segue um longo caminho: primeiro a Fundação Nacional do Índio (FUNAl) identifica a região e o povo que a ocupa. Posteriormente, o Ministério da Justiça declara a terra de ocupação indígena, define os limites, colocando marcos de cimento. Muito mais tarde é feita a demarcação, que é homologada pelo Presidente da República. Todas essas etapas são em geral muito demoradas, especialmente quando existem conflitos de interesse econômico.

Quando Silvio, um dos informantes foi questionado sobre como ele percebe o direito à terra na aldeia do Karuguá, ele relatou que:

(...) aqui na aldeia é ruim, nóis não tem terra pra plantar ... tem muito negócio de meio ambiente, tem um monte de gente que vem aqui e fala ... que aqui não pode plantar nada, derrubar a mata ... aqui é mais difícil, por que aqui não pode plantar nada ... branco não pode pesca, mas nós pode às vez e caçá, às vez (...) (SILVIO, 2007 - grifos das autoras).

De acordo com outro informante, quando questionado sobre a possibilidade de pescar na represa, ele relatou que: "na época de peixe dá pra pesca, dá pra comer só peixe ... na represa tem peixe, lambarizinho ..." Mesmo sabendo das proibições impostas pelo órgão ambiental responsável pela área, os Mbyá-Guarani buscam seus alimentos na época em que eles sabem que encontrarão.

Assim, os Mbyá-Guarani estão sempre à procura de novas áreas, "com melhores recursos ecológicos, onde possam viver conforme a sua tradição [...]". Nessas áreas faz-se necessário "um mato com espécies variadas ... As matas significam o único meio de sobrevivência física e cultural deste grupo" (TEMPASS, 2005).

Portanto, a localização ideal de uma aldeia Mbyá-Guarani, em locais que existam recursos naturais disponíveis, é imprescindível para que seja garantido direito humano a uma alimentação permanente, adequada em qualidade e em quantidade, ambientalmente sustentável e culturalmente aceita.

Espaço Ameríndio, Porto Alegre, v. 2, n. 1, p. 129-165, jan./jun. 2008. 


\section{Considerações finais}

A expulsão dos indígenas de suas terras legítimas por disputas territoriais, a degradação ambiental ou a impossibilidade de cultivar a terra e viver dos recursos disponíveis nas matas, além de muitos grupamentos indígenas viverem em proximidades das cidades (áreas de ocupação urbana, rodovias, etc.) têm impedido que os indígenas vivam de acordo com seu modo de vida tradicional. Todas essas transformações têm sido quantificadas nos estudos sobre o perfil de saúde, apontando prevalências de doenças infecto contagiosas e carenciais. A alimentação e nutrição inadequadas estão evidenciadas nos dados de desnutrição em crianças e adultos indígenas em diversas etnias e regiões do país, mas sobretudo discutimos aqui a insegurança alimentar do ponto de vista cultural a que os indígenas são submetidos. Em muitas aldeias espalhadas pelo território brasileiro, como acontece no Karuguá, pela impossibilidade de cultivarem suas roças, de praticarem a coleta de frutos ou a caça no mato e pela proibição da pesca na represa, os indígenas vivem em total insegurança alimentar e nutricional, desnutrindo não só o corpo, mas também a alma guarani. As regras alimentares que os Mbyá-Guarani devem obedecer, destacando-se as que pró́bem o consumo de alimentos industrializados, para que alcancem a pureza da sua alma e a leveza dos seus corpos, para ficarem mais próximos à Nhanderu, é tolhida pelas desobediências às regras alimentares, o que pode causar nesse grupo conflitos em relação aos seus costumes.

Apesar das condições difíceis de sobrevivência no Karuguá, como falta de alimentos, como as dificuldades para viverem de acordo com as suas concepções de vida tradicional, eles ainda assim, manifestam vontade de viver lá, pois pelo isolamento geográfico conseguem conter as interferências da sociedade envolvente.

\section{Referências bibliográficas}

Espaço Ameríndio, Porto Alegre, v. 2, n. 1, p. 129-165, jan./jun. 2008. 
BONAMIGO, Zélia Maria. A Ecomonia dos Mbyá-Guaranis: Trocas entre Homens e entre Deuses e Homens na Ilha da Cotinga em Paranaguá-PR. 2006. 165 f. Dissertação (Mestrado em Antropologia Social) - PPGAS/Setor de Ciências Humanas, Letras e Artes, Universidade Federal do Paraná, [2006].

BRAND, Antônio. O impacto da perda da terra sobre a tradição Kaiová/Guarani: os difíceis caminhos da palavra. 1997. 390 f. Tese (Doutorado em Antropologia) PUC-RS, [1997].

BRASIL. Lei n. 6001, de 19 de dezembro de 1973. República Federativa do Brasil. Brasília: Senado Federal, 1973.

Constituição: República Federativa do Brasil. Brasília: Senado Federal, 1988.

Lei n. 9985, de 18 de julho de 2000. República Federativa do Brasil. Brasília:

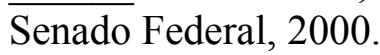

CANESQUI, Ana Maria; GARCIA, Rosa Wanda D. Uma Introdução à reflexão sobre a Abordagem Sociocultural da Alimentação. In: CANESQUI, Ana Maria. Antropologia e nutrição: um diálogo possível. Rio de Janeiro: FIOCRUZ, 2005. p. 9-19.

CAPELLI, Jane C. S.; KOIFMAN, Sergio. Avaliação do estado nutricional da comunidade indígena Parkatêjê, Bom Jesus do Tocantins, Pará, Brasil. Cad. Saúde Pública, Rio de Janeiro, v. 17, n. 2, p. 433-437, mar./abr. 2001. Disponível em: http://www.scielo.br/pdf/csp/v17n2/4188.pdf . Acesso em: 15 jun. 2008.

COIMBRA JR, Carlos A.; SANTOS, Ricardo V. Avaliação do Estado Nutricional num Contexto de Mudança Sócio-Econômica: o Grupo Indígena Suruí do estado de Rondônia, Brasil. Cad. Saúde Pública, Rio de Janeiro, v.7, n.4, p. 538-562, out./dez. 1991. Disponível em: www.scielosp.org/scielo.php?script $=$ sci arttext\&pid $=\mathrm{S} 0102-$

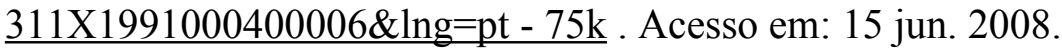

CONFALONIERI, Ulisses E. C. O Sistema Único de Saúde e as Populações Indígenas: Por uma integração diferenciada. Cad. Saúde Pública, Rio de Janeiro, v.5, n.4, p. 441450, out./dez. 1989. Disponível em: http://www.scielo.br/pdf/csp/v5n4/08.pdf . Acesso em: 15 jun. 2008.

CTI. Centro de Trabalho Indigenista. Disponível em: http://www.trabalhoindigenista.or.br . Acesso em: 02 nov. 2007.

DIEHL, Eliana E. Agravos na saúde Kaingáng (terra Indígena Xapecó, Santa Catarina) e a estrutura dos serviços de atenção biomédica. Cad. Saúde Pública, Rio de Janeiro, v. 17, n. 2, p. 439-445, mar./abr. 2001. Disponível em: http://www.scielo.br/pdf/csp/v17n2/4189.pdf . Acesso em: 15 jun. 2008.

FÁVARO, Thatiana et al. Segurança alimentar em famílias indígenas Teréna, Mato Grosso do Sul, Brasil. Cad. Saúde Pública, Rio de Janeiro, v. 23, n. 4, p. 785-793, abr. 
2007. Disponível em: http://www.scielo.br/pdf/csp/v23n4/05.pdf . Acesso em: 15 jun. 2008 .

FELIPIM, Adriana P. O sistema agrícola guarani mbyá e seus cultivares de milho: um estudo de caso na aldeia Guarani da Ilha do Cardoso, município de Cananéia, SP. 2001. 135 f. Dissertação. (Mestrado em Ciências) - Escola Superior de Agricultura Luis de Queiroz, Universidade de São Paulo, [2001]. Disponível em: http://www.trabalhoindigenista.org.br/Docs/guarani milho.pdf . Acesso em: 15 jun. 2008.

FERREIRA, Luciane M. Mbá e achy: a concepção cosmológica da doença entre os mbyá guarani num contexto de relações interétnicas. 2001. 159 f. Dissertação (Mestrado em Antropologia Social) - PPGAS, UFRGS, [2001].

FREITAS, Maria do Carmo S. de; PENA, Paulo G. L. Segurança alimentar e nutricional: a produção do conhecimento com ênfase nos aspectos da cultura. Rev. Nutrição, Campinas, v. 20, n. 1, p. 69-81, jan./fev. 2007. Disponível em: http://www.scielo.br/scielo.php?script $=$ sci arttext\&pid $=S 1415-52732007000100008 \&$

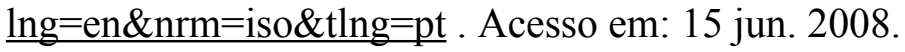

FUNAI. Fundação Nacional do Índio. Disponível em: http://www.funai.gov.br . Acesso em : 08 set. 2007.

GARLET, Ivori. Mobilidade Mbyá: história e significações. 1997. 190 f. Dissertação (Mestrado em História) - PPGH, PUC-RS, [1997].

GRACIA ARNÁIZ, Mabel. Em direção a uma Nova Ordem Alimentar? In: CANESQUI, Ana Maria. Antropologia e nutrição: um diálogo possível. Rio de Janeiro: FIOCRUZ, 2005. p. 147-166.

GUGELMIN, Sílvia A.; SANTOS, Ricardo V. Ecologia humana e antropometria nutricional de adultos Xavante, Mato Grosso, Brasil. Cad. Saúde Pública, Rio de Janeiro, v. 17, n. 2, p. 313-322, mar./abr. 2001. Disponível em: http://www.scielo.br/pdf/csp/v17n2/4176.pdf. Acesso em: 15 jun. 2008.

HECK, Egon; PREZIA, Benedito. Povos Indígenas: Terra é Vida. São Paulo: Atual, 1999.

HECKLER, Jacimara M. Sementes e saberes: trocas e aprendizados com a cultura Guarani e agroecologia. 2006. 134 f. Dissertação (Mestrado em Educação) - Faculdade de Educação, UFRGS, [2006].

HELM, Cecília M. V. Movimentos indígenas: o caso paranaense. In: BONIM, Anamaria A. et al. Movimentos Sociais no Campo. Curitiba: Criar/Scientia et Labor, 1987. p. 153-161.

HÖKERBERG, Yara H. M.; DUCHIADE, Milena P.; BARCELlOS, Christovam. Organização e qualidade de assistência à saúde dos indígenas Kaingàng do Rio Grande 
do Sul, Brasil. Cad. Saúde Pública, Rio de Janeiro, v. 17, n. 2, p. 261-272, mar./abr. 2001. Disponível em: http://www.scielo.br/pdf/csp/v17n2/4172.pdf . Acesso em: 15 jun. 2008.

LADEIRA, Maria Inês. Os índios guarani/mbya e o complexo lagunar estuarino de Iguape - Paranaguá. São Paulo: Centro de Trabalho Indigenista, 1994.

. Espaço geográfico Guarani-Mbyá: significado, constituição e uso. 2001. 236 f. Tese (Doutorado em Geografia Humana) - PPGGH, USP, [2001]. Unesp, 2007.

O caminhar sob a luz: território mbyá à beira do oceano. São Paulo: Editora

LEITE, Maurício Soares et al. Crescimento físico e perfil nutricional da população indígena Xavante de Sangradouro-Volta Grande, Mato Grosso, Brasil. Cad. Saúde Pública, Rio de Janeiro, v. 22, n. 2, p. 265-276, fev. 2006. Disponível em: http://www.scielo.br/pdf/csp/v22n2/04.pdf . Acesso em: 15 jun. 2008.

LIMA, Cristina Maria Garcia de et al. Pesquisa Etnográfica: iniciando sua compreensão. Rev. Latino-am.enfermagem, Ribeirão Preto, v. 4, n. 1, p. 21-30, jan. 1996. Disponível em: http://www.scielo.br/pdf/rlae/v4n1/v4n1a03.pdf . Acesso em: 15 jun. 2008.

LITAIFF, Aldo. As Divinas Palavras: identidade étnica dos Guarani-Mbyá. Florianópolis: UFSC, 1996.

LITAIFF, Aldo; DARELLA, Maria D. P. Os índios guarani mbyá e o parque estadual da serra do tabuleiro. Reunião Brasileira de Antropologia, 22, 2000, Brasília: ABA, 2000.

MALUF, Renato S. J. Segurança Alimentar e Nutricional. Petrópolis: Vozes, 2007.

MELIÁ, Bartolomeu. A experiência religiosa Guarani. In: MARZAL, Manuel M. et al. O rosto índio de Deus. Petrópolis: Vozes, 1989. p. 293-357.

OLIVEIRA, Maria Aparecida. de. Representações e práticas em saúde bucal entre os Guarani Mbyá da aldeia Boa Vista no município de Ubatuba, São Paulo. 2006. 141 f. Dissertação (Mestrado em Ciências), São Paulo: Coordenadoria do Controle de Doenças da Secretaria de Estado da Saúde de São Paulo, [2006]. Disponível em: http://sis.funasa.gov.br/portal/publicacoes/pub1266.pdf . Acesso em: 15 jun. 2008.

PARANÁ. Decreto n. 1754, de 06 de maio de 1996. Diário Oficial [do] Estado do Paraná, n. 4750, Curitiba, 06 mai. 1996.

PIRAQUARA. Decreto n. 2941, de 25 de abril de 2007. Jornal "Agora Paraná", n. 1674, Piraquara, 03 mai. 2007. 
PISSOLATO, Elizabeth. A duração da pessoa: mobilidade, parentesco e xamanismo mbya (guarani). São Paulo: Unesp, 2007.

PREFEITURA MUNICIPAL DE PIRAQUARA. Disponível em: http://www.piraquara. pr.gov.br . Acesso em: 29 set. 2007.

RIBAS, Dulce L. B. et al. Nutrição e saúde infantil em uma comunidade indígena Teréna, Mato Grosso do Sul, Brasil. Cad. Saúde Pública, Rio de Janeiro, v. 17, n. 2, p. 323-331, mar./abr. 2001. Disponível em: http://www.scielo.br/pdf/csp/v17n2/4177.pdf . Acesso em: 15 jun. 2008.

SANTOS, Ricardo. Crescimento físico e Estado Nutricional de populações indígenas brasileiras. Cad. Saúde Pública, Rio de Janeiro, v. 9, n. 1, p. 46-57, 1993. Disponível em: http://www.scielo.br/scielo.php?script $=$ sci arttext\&pid $=S 0102-311 X 1993000500$ 006. Acesso em: 15 jun. 2008.

TEMPASS, Mártin César. Orerémbiú: a relação das práticas alimentares e seus significados com a identidade étnica e a cosmologia Mbyá-Guarani. 2005. $156 \mathrm{f}$. Dissertação (Mestrado em Antropologia Social), PPGAS, UFRGS, [2005]. Disponível $\mathrm{em}$ : http://www.bibliotecadigital.ufrgs.br/da.php?nrb=000511444\&loc $=2006 \& \mathrm{l}=3519 \mathrm{e}$ 0d5be28fde3 . Acesso em: 15 jun. 2008.

VALENTE, Flávio L. S. Do combate à fome à segurança alimentar e nutricional: o direito à alimentação adequada. Revista de Nutrição da Puccamp, Campinas, v. 10, n. 1, p. 20-36, 1997.

VALENTE, Flávio L. S. et al. Módulo I: Segurança Alimentar e Nutricional (SAN) e o Direito Humano à Alimentação Adequada. In: ABRANDH - Ação Brasileira pela Nutrição e Direitos humanos. Curso de Formação em direito Humano à Alimentação Adequada No Contexto da Segurança Alimentar e Nutricional. Curitiba: ABRANDH, 2007a.

Módulo II: Direitos, Obrigações e as Violações do DHAA. In: ABRANDH Ação Brasileira pela Nutrição e Direitos humanos. Curso de Formação em direito Humano à Alimentação Adequada No Contexto da Segurança Alimentar e Nutricional. Curitiba: ABRANDH, 2007b. 